\title{
Protecting a managed bee pollinator against climate change: strategies for an area with extreme climatic conditions and socioeconomic vulnerability
}

\author{
Tereza C. GianninI ${ }^{1,2}$, Camila MAiA-Silva ${ }^{3}$, Andre L. Acosta ${ }^{2}$, Rodolfo JAFFé ${ }^{1}$, \\ Airton T. Carvalho ${ }^{4}$, Celso F. Martins ${ }^{5}$, Fernando C. V. Zanella ${ }^{6}$, \\ Carlos A. L. Carvalho ${ }^{7}$, Michael Hrncir $^{3}$, Antonio M. Saraiva ${ }^{8}$, \\ José Oswaldo SiqueIrA ${ }^{1}$, Vera L. IMPERATRIZ-FonseCA ${ }^{1,2}$

\begin{abstract}
${ }^{1}$ Instituto Tecnológico Vale (ITV), Rua Boaventura da Silva 955, Belém, Pará, Brazil
${ }^{2}$ Instituto de Biociências da Universidade de São Paulo (IBUSP), Rua do Matão trav. 14, São Paulo, São Paulo, Brazil

${ }^{3}$ Universidade Federal Rural do Semiárido (UFERSA), Rua Francisco Mota 572, Mossoró, Rio Grande do Norte, Brazil

${ }^{4}$ Universidade Federal Rural de Pernambuco (UFRPE), Av. Gregório Ferraz Nogueira, SN. Caixa Postal 063, Serra Talhada, Pernambuco, Brazil

${ }^{5}$ Universidade Federal da Paraíba (UFPB), Castelo Branco, João Pessoa, Paraíba, Brazil

${ }^{6}$ Universidade Federal da Integração Latino-Americana (UNILA) Jd. Universitário, Foz do Iguaçu, Paraná, Brazil

${ }^{7}$ Universidade Federal do Recôncavo da Bahia (UFRB), Rua Rui Barbosa 710, Cruz das Almas, Bahia, Brazil

${ }^{8}$ Escola Politécnica da Universidade de São Paulo (EPUSP), Av. Prof. Luciano Gualberto 380, São Paulo, São Paulo, Brazil
\end{abstract}

Received 23 January 2017 - Revised 27 March 2017 - Accepted 1 June 2017

\begin{abstract}
In the semiarid region of Northeastern Brazil, populations of native bees can be jeopardized by future climate change. The present study aims to analyze the impact of climate change on a native stingless bee (Melipona subnitida Ducke). This species is a locally important pollinator of wild and crop plants, also exploited for honey production by regional beekeepers. Using species distributional modeling, we assessed the effects of climate change on the geographic distribution of M. subnitida. We found a potential shift in future areas where species can find climatically suitable habitats toward the edges of the current pollinator distribution with a consequent central disconnection, which can threaten species dispersal and gene flow. We propose to reconnect the remaining suitable areas through conservation and restoration programs based on the distribution of the plant species that are used by this bee as source of pollen and nectar and propose also, other strategies that aim to increase the welfare of local people
\end{abstract}

conservation / economy / landscape ecology / Melipona subnitida / pollination / restoration / sustainability

\section{INTRODUCTION}

Bee pollinators are under threat from environmental degradation demanding effective strategies

Electronic supplementary material The online version of this article (doi:10.1007/s13592-017-0523-5) contains supplementary material, which is available to authorized users.

Corresponding author: T. Giannini, tereza.giannini@itv.org

Manuscript editor: Alexandra Klein and policies to protect them (Potts et al. 2016). Changes in climate can jeopardize bee species richness and abundance (Papanikolaou et al. 2016), phenology synchronization (Stevenson et al. 2015), and diurnal activity patterns of pollinators (Rader et al. 2013), impacting interaction networks (Hegland et al. 2009; Burkle et al. 2013) and forcing species to shift their distribution ranges (Bartomeus et al. 2013; Kerr et al. 2015). This is particularly important since pollination services provided by native bees are important to the maintenance of ecosystem diversity and on resources and food production (Costanza et al. 2014). 
Programs to protect pollinator and their interactive plants are urgently in need. Successful conservation/restoration practices must consider the definition of priority areas that could facilitate pollinator settlement and mobility (Menz et al. 2011), including features such as landscape properties, deforestation, habitat fragmentation, presence of agricultural areas, or other types of anthropogenic disturbances (Carvalheiro et al. 2011; Kennedy et al. 2013; Garibaldi et al. 2014, 2016). Additionally, conservation/restoration practices should rely on climate change studies because it may not be worthwhile to protect or reintroduce species that will not find suitable habitats in the near future (Harris et al. 2006).

The Northeast of Brazil is a semiarid region that was originally covered by Tropical Dry Forests, known regionally as "Caatinga" (Krol et al. 2001; Prado 2003). The regional climate is very hot semiarid tropical, with a long dry season of 8 to 9 months in some areas; the rainy season is short and irregular and the average annual rainfall is low (300-800 mm). Biodiversity in these areas must support long periods of water stress, and there is a relatively high level of endemism, especially of plants and invertebrates (Leal et al. 2003; Albuquerque et al. 2012). In addition to the harsh climate conditions, inadequate land use practices have increased the risk of desertification in the Caatinga region. Deforestation is advancing on natural areas due to livestock, agriculture, and the use of firewood and charcoal, and the natural vegetation remains at only $54 \%$ of the original area, being the average rate of deforestation equal to $2700 \mathrm{~km}^{2}$ per year (MMA 2011). The soil of these deforested areas becomes drier and more compacted, leading to desertification (Castelletti et al. 2004; Leal et al. 2005; Santana 2007). Moreover, climate change predictions for the Caatinga region are alarming. The average temperature increase in the area is estimated to be between 3.5 and $4.5^{\circ} \mathrm{C}$ by 2100 , and precipitation may suffer average reductions of up to $40-50 \%$ (PBMC 2013), which reinforces the tendency to desertification (Marengo 2011).

Most municipalities in the Caatinga region have a human development index (HDI) ranging from medium to very low (The Brazilian Institute of Geography and Statistics database for the year
2010). In a socioeconomic context of poverty, climate change can bring severe problems due to the small capacity of populations to adapt and accommodate to it. In fact, reports from the Food and Agriculture Organization of the United Nations (FAO 2010) argued that even small changes in climate can have negative impacts in the poorest rural communities, which already live in precarious conditions (see also Poppy et al. 2014). In addition to being more economically and socially fragile, these communities are more dependent on ecosystem services and natural resources for their survival (MEA 2005). For example, 25$30 \%$ of the energy used in Northeastern Brazil comes from its natural vegetation (Riegelhaupt and Pareyn 2010), which leads to intense pressure on the ecosystem. Family farming also is based on local fruit and vegetables that are usually dependent on pollinators (Giannini et al. 2015a).

Our case study uses Melipona subnitida, a stingless bee popularly known as "jandaira." It is a key species for the pollination of both native plants and commercial crops. Previous studies have indicated that these bees are pollinators of pepper (Cruz et al. 2004) and annatto (Mesquita 2008) and can be used in greenhouses (Silva et al. 2005). In addition, $M$. subnitida is an important species traditionally used for honey production in the Caatinga region, providing extra income for farmers and rural families (annual mean of US $\$ 1300$ per stingless beekeeper and annual maximum value equal to US\$15,500) (Jaffé et al. 2015). This species is well adapted to local conditions and can support dry periods, differently from Apis mellifera $\mathrm{L}$. that is a common species in the region and usually migrates during droughts (Maia-Silva et al. 2015). Thus, breeding this native bee is important for the local economy and can be considered an example of activity related to sustainable development.

The main objective of this study is to analyze the impact of climate change on a stingless bee (Melipona subnitida Ducke) managed by local people. We also aim to discuss strategies of conservation and restoration of priority areas to protect the species based on its interacting plant species (used to collect pollen and nectar and to build its nest). As our study area comprises a region with low societal development, we also aim to 
discuss how to protect a species, and at the same time, promote human socioeconomic development under climate change.

\section{MATERIALS AND METHODS}

The study area encompasses Northeastern Brazil under the biome originally classified as Tropical Dry Forest (Figure 1). At the beginning of this study, the geographical distribution of M. subnitida was poorly known and few records were available on a data provider of Brazilian biodiversity (speciesLink website). To fill this information gap, an extensive survey was conducted during the years 2012-2014 that produced almost 250 new records (Figure 1). We used this novel data and the records found on speciesLink (9 records) to perform species distribution modeling (SDM).

SDM is used to determine potential areas of species occurrences and to forecast future potential distribution (Franklin 2009). In addition to occurrence points, SDM uses environmental variables to determine suitable areas for species potential distribution. We used climatic variables obtained from Worldclim (Hijmans et al. 2005) with a resolution of 5 arc-minutes (approximately $10 \times 10 \mathrm{~km}$ cell size at the equator). From the 20 topoclimatic variables available under current climatic conditions, we calculated the nine least correlated variables for the study area, retaining variables with a Pearson's pair-wise correlation coefficient higher than 0.7 (Aguirre-Gutierrez et al. 2013): altitude, mean diurnal range, isothermality, mean temperature of driest quarter, annual precipitation, precipitation of driest month, precipitation seasonality, precipitation of warmest quarter, and precipitation of coldest quarter. We used the same variables to forecast future potential distribution, but projected for the year 2050 by the Met Office Hadley Centre (HadGEM2-CC) and the University of Tokyo and collaborators (MIROC-ESM-CHEM). We built the ensemble forecasting of both projections following Araújo and New (2007). We used the Representative Concentration Pathways (RCP) 8.5, which specifies a likely global mean surface temperature increase by the end of the twenty-first century of 2.6 to $4.8^{\circ} \mathrm{C}$ (IPCC 2014). Despite being considered the most pessimistic scenario, it is also considered the most plausible, since it suggests that the emission of greenhouse gases will continue to grow in the same way than in recent years (IPCC 2014).

To perform SDM, we used the maximum entropy algorithm (Maxent) (Phillips et al. 2006). This algorithm is particularly useful because it can be applied to data sets using only presence-
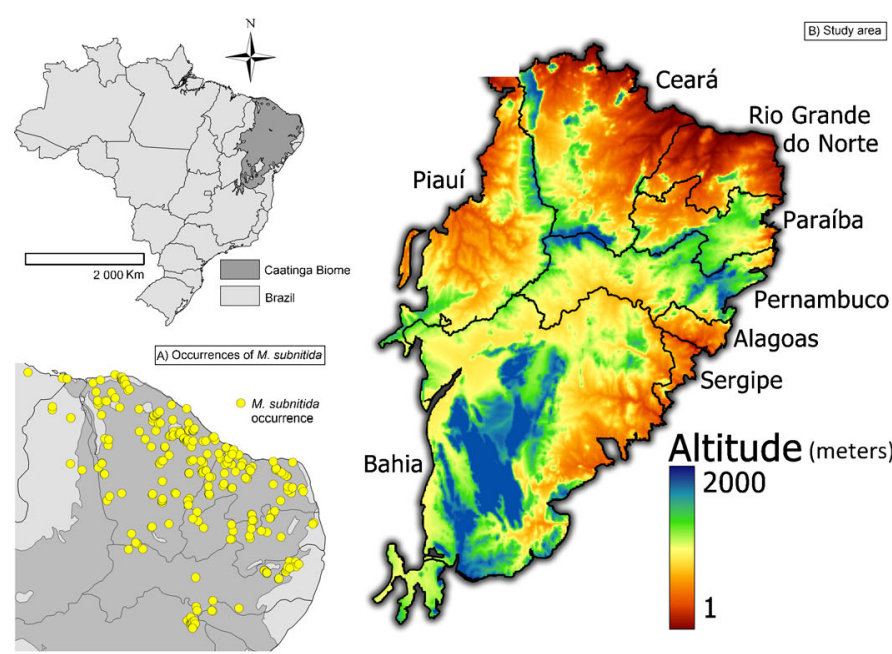

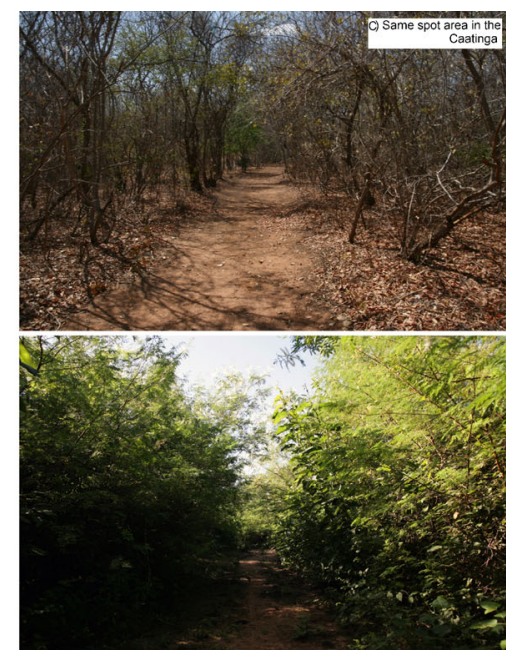

Figure 1. a Study area, b occurrences of Melipona subnitida bees, c the same spot in the Caatinga during dry (above) and wet (below) seasons at the Experimental Farm of the Federal Rural University of the Semi-AridUFERSA, Mossoro, Rio Grande do Norte. 
records of species (as opposed to other algorithms that require absence data) (Wisz et al. 2008). We used the area under the curve (AUC) of the receiver-operator graph to estimate the accuracy of the modeling process in a test data set $(20 \%$ of total occurrence data) (Fielding and Bell 1997) and selected the models with values of AUC higher than 0.9 .

M. subnitida interacts with plant species (Figure 2) and we analyzed the current and future potential distribution of its main resource plants to determine the best future conditions for the pollinator (Giannini et al. 2013a). Therefore, we also analyzed the impact of climate change on 18 foraging plants (used to provide pollen and nectar) determined in a previous work (Maia-Silva 2013, 2015) (Figure 2). Because M. subnitida builds its nests mostly in a few tree species, we also analyzed the potential distribution of eight plants used as nesting sites (Martins et al. 2004) (Figure 2). The occurrences of all plant species were retrieved from speciesLink (Online Resource S1) and were modeled using the same procedure as described above. At the end of the modeling process, we normalized and merged all models obtained for the M. subnitida bee, foraging plants (18 species) and nesting plants (8 species), which resulted in one model of potential distribution for current conditions and one for future conditions (the ensemble forecast of the Had and MIROC scenarios) (following procedure of Giannini et al. 2013b, 2015b). These final models were considered to represent the main areas where bees could find the most suitable climate conditions and mutualistic interactions both now and in the future. All these procedures were performed using the raster package (Hijmans and Etten 2012) of R (The R Project for Statistical Computing).

To create maps informing decision-making, we perform a pixel-by-pixel analysis. Therefore, we first reclassified the above mentioned models to analyze the areas that had more than $50 \%$ occurrence probability, that means, the pixels where, according to models, species showed at least 50\% chance of occurring (Online Resource Fig. S2A). At this stage, we also evaluated (in percentage) the variation in the size of suitable areas detected by the reclassified models considering current and future scenarios to determine if the total amount of potential occurrence area will increase or decrease. Second, we compared current and future models to determine the shift of suitable areas during the time-period analyzed (Fig. S2B). Third, we analyzed deforestation in the same region using a global land cover map from the European Space Agency (ESA GlobCover) for 2009 (Fig. S2C). We reclassified the original data as follows: (i) we considered as being the "natural vegetation class' the types of land cover with no or with minor $(<50 \%)$ human intervention (e.g., broadleaved forest, shrubland, herbaceous vegetation) and (ii) we considered as being the "no natural vegetation class' the types of land cover that were related to human modification (e.g., rainfed, post-flooding or irrigated croplands, artificial areas) and the non-vegetated areas (e.g., water bodies, bare areas). After reclassification, we downscaled the data from the original resolution $(300 \times 300 \mathrm{~m})$ to the topoclimatic variables' resolution $(10 \times 10 \mathrm{~km})$, considering the majority of the class type inside the original set of pixels. We considered the potential priority areas for conservation to be the locations having natural vegetation and, for restoration, the areas with no natural vegetation. Moreover, we used the values of the human development index (HDI) for each municipality to assess the regional socioeconomic vulnerability. These last data were retrieved from The Brazilian Institute of Geography and Statistics (IBGE) for the year 2010 (Fig. S2D). All the analyses were performed only on the Northern area of the Caatinga region because this is the most important occurrence area for $M$. subnitida (Figure 1), and strategic plans for conservation and restoration to protect this bee are currently being considered. All procedures were performed using ArcGIS (Esri Inc.).

\section{RESULTS}

The best currently suitable areas for M. subnitida bees and their plants are located on the northern portion of Caatinga, encompassing mainly the northeastern part of Piauí State and a wide area covering almost the entire extent of Rio Grande do Norte, Paraíba and Pernambuco States, except for a large easternmost belt following the coastline of these three States (Figure 3a). Models 

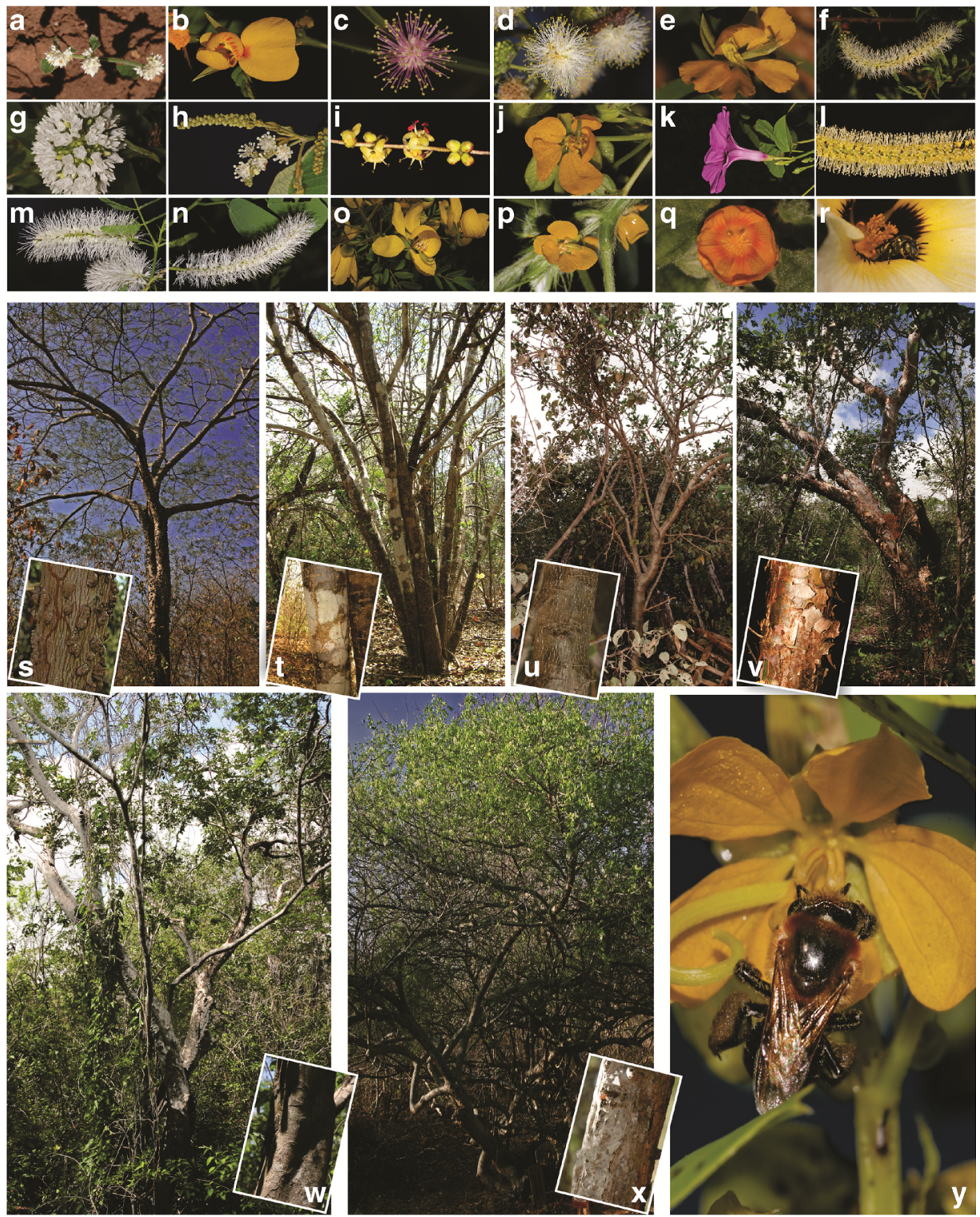

Figure 2. Plants used for nectar and pollen foraging: a Alternanthera tenella Colla; b Chamaecrista duckeana (P. Bezerra \& Afr. Fern.) H. S. Irwin \& Barneby; c Mimosa quadrivalvis L.; d Anadenanthera colubrina (Vell.) Brenan; e Chamaecrista calycioides (DC. ex Collad.) Greene; f Mimosa tenuiflora (Willd.) Poir.; g Borreria verticillata (L.) G. Mey.; h Croton sonderianus Müll. Arg.; i Myracrodruon urundeuva Allemão; j Senna obtusifolia (L.); k Ipomoea asarifolia (Desr) Roem. \& Schult.; l Pityrocarpa moniliformis (Benth) Luckow \& R. W. Jobson; m Mimosa arenosa (Willd.) Poir.; n Mimosa caesalpiniifolia Benth.; o Senna trachypus (Benth.) H. S. Irwin \& Barneby; p Senna uniflora (Mill.) H. S. Irwin \& Barneby; and q Sida cordifolia L.; r Turnera subulata Sm. Plants used for nesting: s Anadenanthera colubrina (Vell.) Brenan; t Aspidosperma pyrifolium Mart.; u Cnidoscolus quercifolius Pohl; v Commiphora leptophloeos (Mart.) J. B. Gillett; w Poincianella pyramidalis (Tul.) L. P. Queiroz; and $\mathbf{x}$ Spondias tuberosa Arruda. Bee: y Melipona subnitida Ducke (jandaíra) on Senna obtusifolia. Licania rigida Benth. and Piptadenia gonoacantha (Mart.) J. F. Macbr were also included in the modeling procedure as nesting plants (no photo included). 

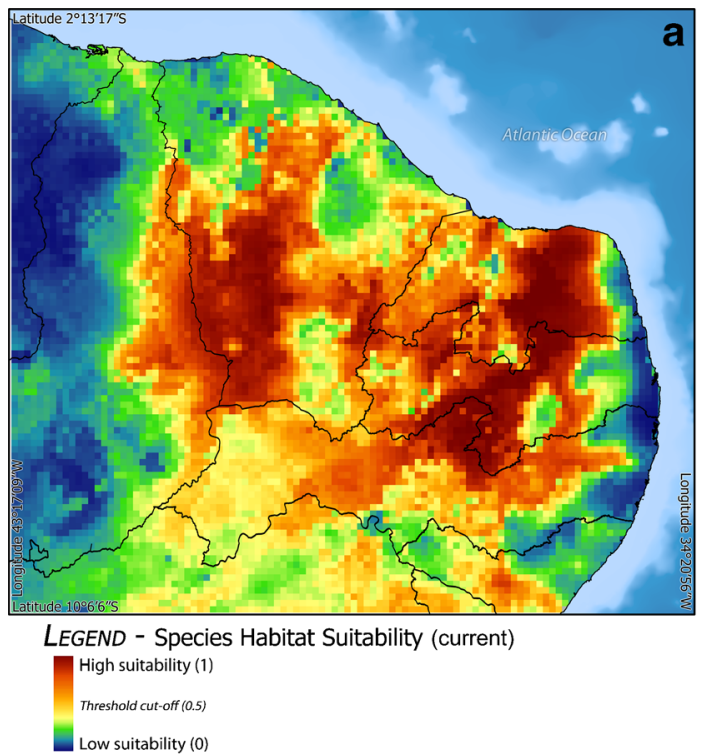

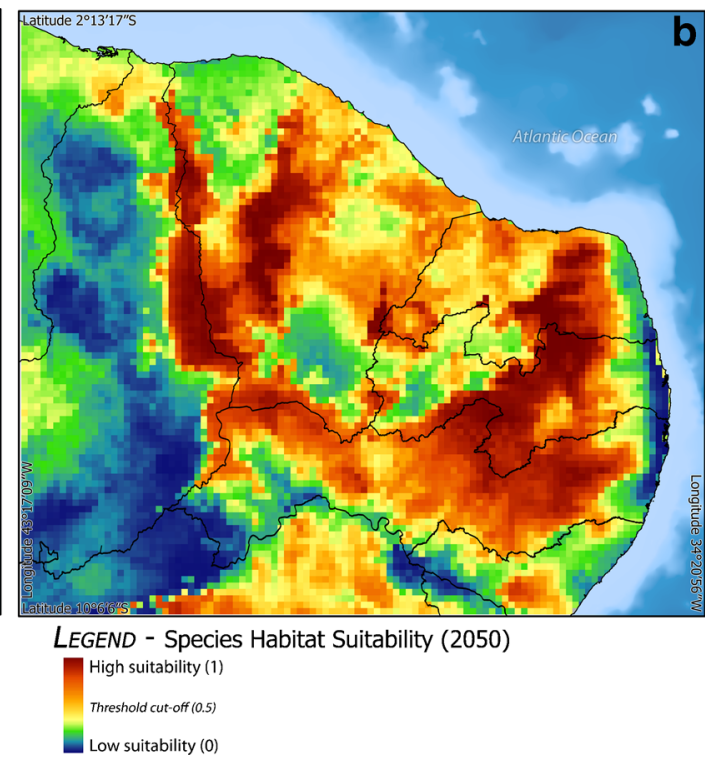

Figure 3. The most suitable areas for Melipona subnitida bees and their nesting and foraging plants considering a current and $\mathbf{b}$ future climatic conditions. The future scenario accounts for 2050 and RCP8.5 emissions.

show that these two major western and eastern areas are mainly connected in western Pernambuco State by a wide central area with high suitability crossing the east of Ceará State.

Future climate indicates that the most suitable areas of occurrence are similar in size (the area increases by $1.4 \%$ under the future scenario), but their location will shift toward the external borders of the study area with respect to their previous distribution (Figure 3b; Fig. S2B). The main external areas coincide with the elevated areas present in the border of Piauí and Ceará states and also in the western areas of Rio Grande do Norte, Paraíba, and Pernambuco (Figure 3b), which comprise much of the Ibiapaba, Araripe, and Borborema Plateaus. However, the main central corridor of suitable areas detected in the current climatic scenario is likely to decrease because most of the region between them will become less suitable due to climate change. However, small patches of highly suitable areas can still be found. The best region for reconnecting the two main suitable areas from now to the future are located on the southern belt of the suitable areas (the borders of the Pernambuco, Paraíba, and Piauí states) because the distance between both main areas is the smallest.
Most of the western and eastern regions with high suitability still have natural vegetation (Fig. S2C) and also medium to high values of HDI (darker blue areas on Figure 4). However, the southern portions of areas exhibiting high suitability contain several locations that no longer have natural vegetation and that coincide with lower HDI areas (light orange areas on Figure 4). The strategic area that may connect both areas in the middle-south has natural vegetation and a slightly higher HDI (Figure 4, Fig. S2C, and S2D)

\section{DISCUSSION}

Our results indicate that the total area suitable for $M$. subnitida will change little in consequence of the predicted future climate change. This, however, does not mean that climate change will have no impact whatsoever on the distribution of this stingless bee species, given that the location of the best environmentally suitable areas will shift toward the edges of their current distribution. This shift follows higher altitudes where both the bees and their plant resources likely find suitable climate conditions under future scenarios of climate warming. This tendency was reported for some 


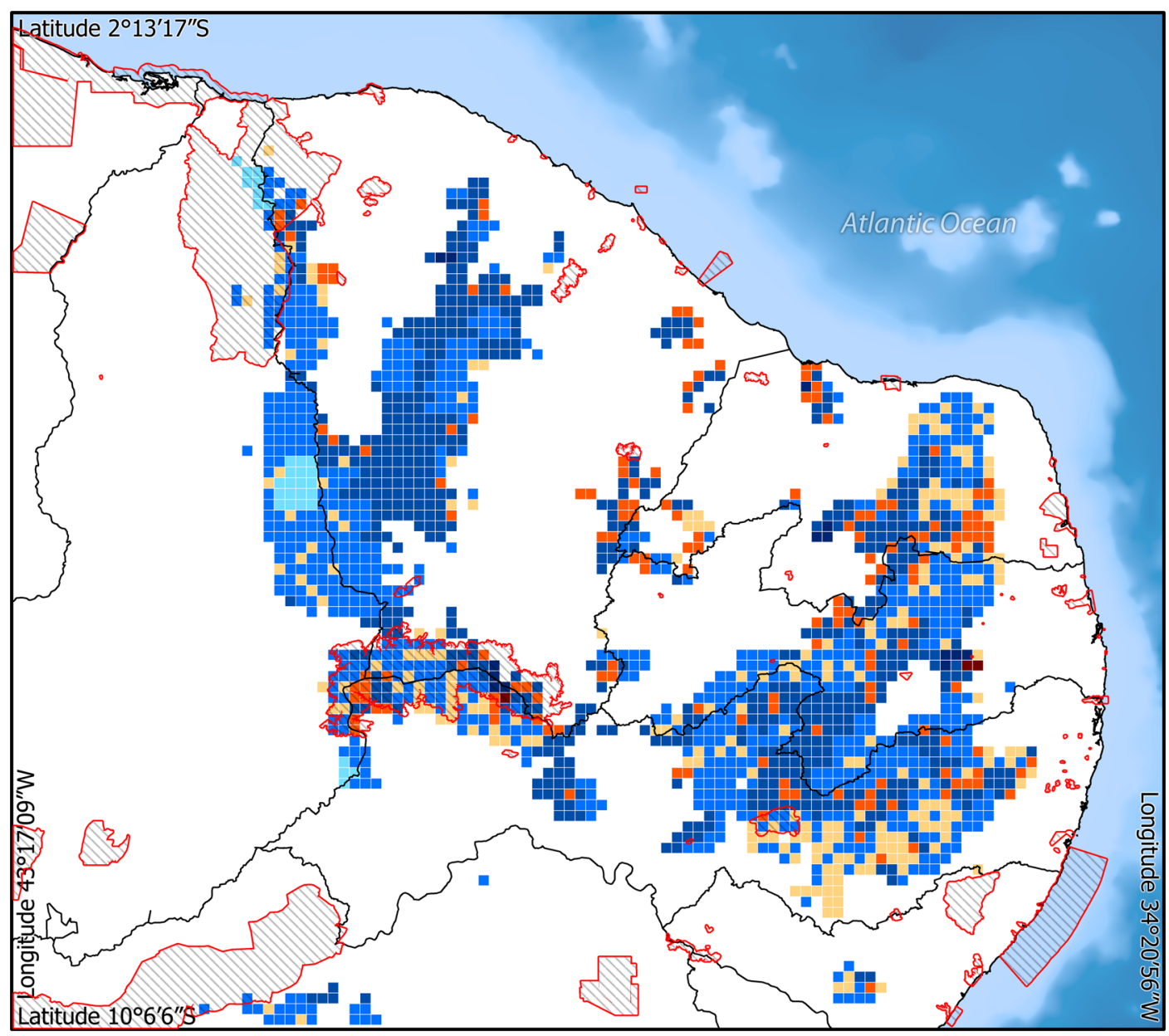

LEGEND - Priority Areas to Restore or Conserve

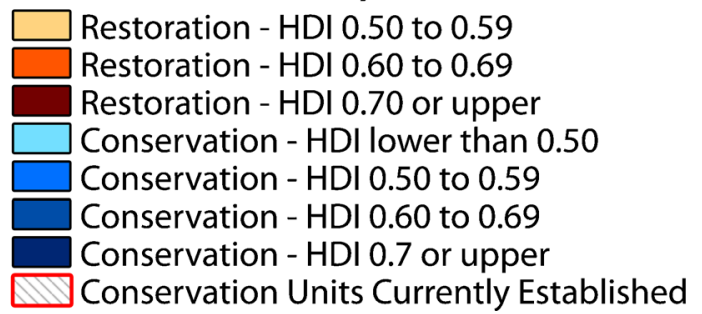

Figure 4. Priority areas for conservation and restoration using potential distribution models, socioeconomic vulnerability, and land cover.

species that have already changed their distribution toward milder climatic conditions at higher altitudes when facing climate-forced dispersal (Parolo and Rossi 2008; Chen et al. 2009). The predicted loss of suitable habitat in the central area of study region will likely result in a shift of the geographic occurrence of $M$. subnitida populations, causing a disruption of the currently connected main occurrence areas. This central area is an important area for the models of current potential occurrence, presenting also, several records of M. subnitida. This poses a considerable problem 
for the preservation of this species by contributing to the isolation of populations and reducing the gene flow between them.

Traditional strategies for preventing isolation could be used, such as the implementation of ecological corridors. However, most of the central areas show low future suitability and, consequently, may not provide proper environmental conditions to ensure their permanence. The most appropriate area predicted for this kind of strategy is located at the southern part of the future geographic distribution of M. subnitida, given that it presents both a high degree of suitability and only a small gap of occurrence. This area could be considered as a priority area for conservation and restoration strategies.

HDI demonstrated that the priority area analyzed for restoration and conservation is inhabited by human populations with different socioeconomic profiles. As mentioned earlier, areas with higher levels of poverty need attention, as populations are potentially more vulnerable to climate change and are also dependent on natural resources. Thus, these areas should be targeted by different conservation and restoration strategies, aiming not only to protect biodiversity but also to improve human well-being. Biodiversity-friendly agroecosystems could be suggested (Dicks et al. 2016). The agricultural areas could be enriched with plants that are used by bees to forage and as nest sites (Buckley and Nabhan 2016) forming "nectar corridors" (Allen-Wardell et al. 1998), thus helping the bees to find suitable conditions for survival, as well as providing potential resources to human welfare. Other strategies for this agroecosystem areas could be to increase beekeeping practices, which can be adopted as a profitable and sustainable alternative (QuezadaEuan et al. 2001; Cortopassi-Laurino et al. 2006; Jaffé et al. 2015). Ecotourism could also be improved, especially in well preserved areas with high scenic value (Nahuelhual et al. 2013) or cultural heritage (Bushell and Eagles 2007).

Additionally, in the priority southern area, one can find natural sites protected by law as national areas for conservation. The proposed priority area for conservation and restoration could also contribute to the reconnection of these areas. Bee diversity in this priority southern area, reported on biological collection and retrieved from specieslink website, comprises 76 species. From those, there are important species already quoted as crop pollinators in Brazil (Giannini et al. 2015c), such as those belonging to Meliponini tribe (28 species), Centris (12), Bombus (1), and Xylocopa (3) genera. Currently, only $14 \%$ of the Caatinga is protected by law as national areas of conservation (Gariglio et al. 2010; Sparovek et al. 2010). Therefore, establishing ecological corridors that connect protected areas could facilitate the dispersal and migration of species and contribute to mitigate the loss of biodiversity and enhance sustainable development in rural communities.

The impact of climate change on crop pollinator bees in Brazil was so far investigated with pollinators of passionfruit (Giannini et al. 2013b) and coffee (Giannini et al. 2015b). The only study related to Northeastern Brazil showed that Centris hyptidis Ducke, 1908 and Centris trigonoides Lepeletier, 1841 (two oil collecting bees that pollinate acerola and cashew) as well Melipona scutellaris Latreille, 1811 (another stingless bee that pollinates avocado and guava) presented 9$35 \%$ of potential reduction in their occurrence areas, depending on the future scenario analyzed (Giannini et al. 2012). This is even more worrying given that the Caatinga presents a lower bee richness when compared to other areas of South America (187 species and 77 genera) (Zanella 2000), which makes its native bee species specially important as ecosystem service providers. Thus, strategies aiming to restore or conserve areas on Northeastern Brazil are urgent in order to contribute on safeguarding pollinators against climate change.

\section{CONCLUSION}

The effects of climate change on species distribution have already been reported, and they require strategic measures for protecting biodiversity. Conservation and restoration strategies aiming to protect biodiversity should consider the types of land use and also the socioeconomic development in the region. Therefore, the use of biodiversity-friendly agroecosystem strategies, beekeeping, and ecotourism in key areas, enriched 
with the plants used by bees to forage and nesting, are suggested to provide additional economic income while protecting the pollinator species. By implementing these strategies, it may be possible to conserve or restore species biodiversity and ensure the ecosystem services delivered by pollinators, as well as increase the economic income and welfare of the local population.

\section{ACKNOWLEDGMENTS}

We thank Bruno A. Souza, Rogério M. O. Alves, Dirk Koedam, and Ulysses Madureira Maia for support during the execution of Projeto Jandaíra and The Brazilian Agricultural Research Corporation (Embrapa Meio Norte) (Projeto Jandaíra). We also thank Lucas Alejandro Garibaldi for suggestions on the manuscript and also The National Council for Scientific and Technological Development (CNPq) (309914/2013-2, 404156/2013-4, 472702/2013-0, 150335/2013-0, 478982/2013-5, 302976/2015-9), the São Paulo Research Foundation (FAPESP) (2015/19217-5), CAPES (55/2013-Pró-Integração), AUXPE (3168/2013) and the Research Center on Biodiversity and Computing (BioComp).

\section{AUTHOR CONTRIBUTIONS}

TCG ALA CSM RJ conceived research; CSM determined botanical data; ATC CFM FCVZ CALC surveyed bee pollinators; TCG ALA performed modeling; TCG CMS MH wrote the manuscript; all authors edited.

Protection d'un pollinisateur contre le changement climatique: stratégies concernant une zone avec des conditions climatiques extrêmes et une vulnérabilité socio-économique

conservation / économie / écologie du paysage / Melipona subnitida / pollinisation / restoration du milieu / durabilité

Schutz eines gemanagten Bienen-Bestäubers vor Klimaveränderungen: Strategien für ein Gebiet mit extremen klimatischen Konditionen und sozioökonomischer Anfälligkeit

Naturschutz / Ökonomie / Landschaftsökologie / Melipona subnitida / Bestäubung / Restauration / Nachhaltigkeit

\section{REFERENCES}

Aguirre-Gutierrez, J., Carvalheiro, L.G., Polce, C., Loon, E.E., Raes, N., Reemer, M., Biesmeijer, J. (2013). Fitfor-purpose: species distribution model performance depends on evaluation criteria. Dutch hoverflies as a case study. PlosOne 8, e63708.

Albuquerque, U.P., Araújo, E.L., El-Deir, A.C.A., Lima, A.L.A., Souto, A., et al. (2012). Caatinga revisited: ecology and conservation of an important seasonal dry forest. The Scientific World Journal ID 205182, doi $10.1100 / 2012 / 205182$.

Allen-Wardell, G., Bernhardt, P., Bitner, R., Burquez, A., Buchmann, S., et al. (1998). The potential consequences of pollinator declines on the conservation of biodiversity and stability of food crop yields. Conserv. Biol. 12, 8-17

Araújo, M.B., New, M. (2007). Ensemble forecasting of species distributions. TREE 22, 42-47.

Bartomeus, I., Ascher, J.S., Gibbs, J., Danforth, B.N., Wagner, D.L., Hedtke, S.M., Winfree, R. (2013). Historical changes in northeastern US bee pollinators related to shared ecological traits. PNAS 110 , 4656-4660

Buckley, S., Nabhan, G.P. (2016). Food chain restoration for pollinators: regional habitat recovery strategies involving protected areas of the southwest. Nat. Areas J. 36, 489-497.

Burkle, L. A., Marlin, J. C., Knight, T. M. (2013). Plantpollinator interactions over 120 years: Loss of species, co-occurrence, and function. Science 339, 1611-1615.

Bushell, R., Eagles, P.F.J. (2007). Tourism and protected areas: benefits beyond boundaries. IUCN and Cabi, Oxfordshire.

Carvalheiro, L.G., Veldtman, R., Shenkute, A.G., Tesfay, G.B., Pirk, C.W.W., Donaldson, J.S., Nicolson, S.W. (2011). Natural and within-farmland biodiversity enhances crop productivity. Ecol. Lett. 14, 251-9.

Castelletti, C.H.M., Silva, J.M.C., Tabarelli, M., Santos, A.M.M. (2004). Quanto ainda resta da caatinga?, in: Silva, J.M.C., Tabarelli, M., Fonseca, M.T., Lins, L.V. (Eds.), Biodiversidade da caatinga. Ministério do Meio Ambiente, Brasília, pp. 92-100.

Chen, C., Shiu, H.J., Benedick, S., Holloway, J.D., Chey, V.K., Barlow, H.S., Hill, J.K., Thomas, C.D. (2009). Elevation increases in moth assemblages over 42 years on a tropical mountain. Proc. Nat. Acad. Sci. 106, 1479-1483.

Cortopassi-Laurino, M., Imperatriz-Fonseca, V.L., Roubik, D.W., Dollin, A., Heard, T., Aguilar, I.B., Venturieri, G.C., Eardley, C., Nogueira-Neto, P. (2006.) Global meliponiculture. Apidologie 37, 275-292.

Costanza, R., de Groot, R.S., Sutton, P., van der Ploeg, S., Anderson, S.J., Kubiszewski, I., Farber, S., Turner, R.K. (2014). Changes in the global value of ecosystem services. Glob. Environ. Change 26, 152-158.

Cruz, D.O., Freitas, B.M., Silva, L.A., Silva, E.M.S., Bomfim, I.G.A. (2004). Adaptação e comportamento 
de pastejo da abelha jandaíra (Melipona subnitida Ducke) em ambiente protegido. Maringá 26, 293-298.

Dicks, L.V., Viana, B., Bommarco, R., Brosi, B., Arizmendi, M.C., Cunningham, S.A., Galetto, L., Hill, R., Lopes, A.V., Pires, C., Taki, H., Potts, S.G. (2016). Ten policies for pollinators. Science 354, 975-976

FAO - Food and Agriculture Organization of the United Nations (2010). "Climate-Smart" agriculture. policies, practices and financing for food security, adaptation and mitigation. FAO, Rome.

Fielding, A.H., Bell, J.F.A. (1997). Review of methods for the assessment of prediction errors in conservation presence/absence models. Environ. Conserv. 24, 3849.

Franklin, J. (2009). Mapping species distribution. Spatial inference and prediction. Cambridge Press, New York.

Garibaldi, L.A., Carvalheiro, L.G., Leonhardt, S.D., Aizen, M.A., Blaauw, B.R., Isaacs, R., Kuhlmann, M., Kleijn, D., Klein, A.M., Kremen, C., Morandin, L., Scheper, J., Winfree, R. (2014). From research to action: enhancing crop yield through wild pollinators. Front. Ecol. Environ. 12, 439-447.

Garibaldi, L.A., Gemmill-Herren, B., D’Annolfo, R., Graeub, B.E., Cunningham, S.A., Breeze, T.D. (2016). Farming approaches for greater biodiversity, livelihoods, and food security. Trends Ecol. Evol. 2167. doi. 10.1016/j.tree.2016.10.001.

Gariglio, M.A., Sampaio, E.V.S.B., Cestaro, L.A., Kageyama, P.Y. (2010). Uso sustentável e conservação dos recursos florestais da caatinga. Serviço Florestal Brasileiro, Brasília.

Giannini, T.C., Acosta, A.L., Garófalo, C.A., Saraiva, A.M., Alves-dos-Santos, I., Imperatriz-Fonseca, V.L. (2012). Pollination services at risk: Bee habitats will decrease owing to climate change in Brazil. Ecol. Model. 244, 127-131.

Giannini, T.C., Chapman, D., Biesmeijer, J., Saraiva, A.M., Alves dos Santos, I. (2013a). Improving species distribution models using biotic interactions: a case study of parasites, pollinators and plants. Ecography 36, 649656.

Giannini, T.C., Acosta, A.L., Silva, C.I., Oliveira, P.E.A.M., Imperatriz-Fonseca, V.L., Saraiva, A.M. (2013b). Identifying the areas to preserve passion fruit pollination service in Brazilian Tropical Savannas under climate change. Agric. Ecosyst. Environ. 171, 3946.

Giannini, T. C.; Cordeiro, G. D.; Freitas, B.; Saraiva, A. M.; Imperatriz-Fonseca, V. L. (2015a). The dependence of crops for pollinators and the economic value of pollination in Brazil. J. Econ. Entomol. 108, 839-848.

Giannini, T. C., Tambosi, L. R., Acosta, A. L., Jaffé, R., Saraiva, A. M., Imperatriz-Fonseca, V. L., Metzger, J. P. (2015b). Safeguarding ecosystem services: a methodological framework to buffer the joint effect of habitat configuration and climate change. PlosOne 10, e0129225.

Giannini, T. C., Boff, S., Cordeiro, G. D., Cartolano, E. A., Veiga, A. K., Imperatriz-Fonseca, V. L., Saraiva, A. M. (2015c). Crop pollinators in Brazil: a review of reported interactions. Apidologie 46, 209-223.

Harris, J.A., Hobbs, R.J., Higgs, E., Aronson, J. (2006). Ecological restoration and global climate change. Restor. Ecol. 14, 170-176.

Hegland, S.J., Nielsen, A., Lazaro, A., Bjerknes, A.L., Totland, O. (2009). How does climate warming affect plant-pollinator interactions? Ecol. Lett. 12, 184-195.

Hijmans, R.J., Etten, J. (2012). raster: Geographic analysis and modeling with raster data. $\mathrm{R}$ package version 2.0 12.

Hijmans, R., Cameron, S., Parra, J., Jones, P.G., Andy, J. (2005). Very high resolution interpolated climate surfaces for global land areas. Int. J. Climatol. 25, 19651978.

IPCC - Intergovernmental Panel on Climate Change. (2014). Climate Change 2014: Synthesis Report. IPCC, Geneva.

Jaffé, R., Pope, N., Carvalho, A.T., Maia, U.M., Blochtein, B., et al. (2015). Bees for development: Brazilian survey reveals how to optimize stingless beekeeping. PlosOne 10: e0130111.

Kennedy, C.M., Lonsdorf, E., Neel, M.C., Williams, N.M., Ricketts, T.H., et al. (2013). Global quantitative synthesis of local and landscape effects on wild bee pollinators in agroecosystems. Ecol. Lett. 16, 584-599.

Kerr, J.T., Pindar, A., Galpern, P., Packer, L., Potts, S.G., et al. (2015). Climate change impacts on bumblebees converge across continents. Science 349, 177-180.

Krol, M.S., Jaeger, A., Bronstert, A., Krywkow, J. (2001). The Semi-Arid Integrated Model (SIM), a regional integrated model assessing water availability, vulnerability of ecosystems and society in NE-Brazil. Phys. Chem. Earth 26, 529-533.

Leal, I. R., Tabarelli, M., Silva, J. M. C. (eds.) (2003). Ecologia e conservação da caatinga. UFPE, Recife.

Leal, I., Silva, J.M.C., Tabarelli, M., Lacher Jr., T.E. (2005). Mudando o curso da conservação da biodiversidade na caatinga do nordeste do Brasil. Megadiversidade 1, 139-146.

Maia-Silva, C. (2013) Adaptações comportamentais de Melipona subnitida (Apidae, Meliponini) às condições ambientais do semiárido brasileiro. PhD thesis. University of São Paulo.

Maia-Silva, C., Hrncir, M., Silva, C.I., Imperatriz-Fonseca, V.L. (2015). Survival strategies of stingless bees (Melipona subnitida) in an unpredictable environment, the Brazilian tropical dry forest. Apidologie 46, 631-643.

Marengo, J.A. (2011). Dangerous climate change in Brazil. Centro de Ciência do Sistema Terrestre (CCST) of the Instituto Nacional de Pesquisas Espaciais (INPE), Brazil, and the Met Office Hadley Centre.

Martins, C.F., Cortopassi-Laurino, M., Koedam, D., Imperatriz-Fonseca, V.L. (2004). Tree species used for nidification by stingless bees in the brazilian caatinga (Seridó, PB; João Câmara, RN). Biota Neotrop. 4, 1-8. 
MEA - Millennium Ecosystem Assessment. (2005). Ecosystems and human well-being: health synthesis. World Health Organization, Switzerland.

Menz, M.H.M., Phillips, R.D., Winfree, R., Kremen, C., Aizen, M.A., Johnson, S.D., Dixon, K.W. (2011). Reconnecting plants and pollinators: challenges in the restoration of pollination mutualisms. Trends Plant Sci., 4-12.

Mesquita, F.L.A. (2008). Abelhas visitantes das flores do Urucuzeiro (Bixa orellana L.) e suas eficiências de polinização. MSc thesis. Universidade Federal do Ceará.

MMA - Ministério do Meio Ambiente. (2011). Subsídios para a elaboração do plano de ação para a prevenção e controle do desmatamento da caatinga. MMA, Brasília.

Nahuelhual, L., Carmona, A., Lozada, P., Jaramillo, A., Aguayo, M. (2013). Mapping recreation and ecotourism as a cultural ecosystem service: an application at the local level in Southern Chile. Appl. Geogr. 40, 71-82.

Papanikolaou, A.D., Kuhn, I, Frenzel, M., Schweiger, O. (2016). Semi-natural habitats mitigate the effects of temperature rise on wild bees. J. Appl. Ecol. doi: 10.1111/1365-2664.12763.

Parolo, G., Rossi, G. (2008). Upward migration of vascular plants following a climate warming trade in the Alps. Basic Appl. Ecol. 9, 100-107.

PBMC - Painel Brasileiro de Mudanças Climáticas. (2013). Sumário Executivo. PBMC, Rio de Janeiro.

Phillips, S.J., Anderson, R.P., Schapire, R.E. (2006). Maximum entropy modeling of species geographic distributions. Ecol. Model. 190, 231-259.

Poppy, G.M., Chiotha, S., Eigenbrod, F., Harvey, C.A., Honzak, M., et al. (2014). Food security in a perfect storm: using the ecosystem services framework to increase understanding. Phil. Trans. R. Soc. B 369, 20120288.

Potts, S.G., Imperatriz-Fonseca, V., Ngo, H.T., Aizen, M.A., Biesmeijer, J.C., Breeze, T.D., Dicks, L.V., Garibaldi, L.A., Hill, R., Settele, J., Vanbergen, A.J.
(2016). Safeguarding pollinators and their values to human well-being. Nature 540, 220-229.

Prado, D. (2003) As caatingas da América do Sul, in: Leal, I.R., Tabarelli, M., Silva, J.M.C., (eds.). Ecologia e Conservação da caatinga. UFPE, Recife, pp. 75-134.

Quezada-Euan, J., May-Itza, W., González-Acereto, J. (2001). Meliponiculture in México: problems and perspective for development. Bee World 82, 160-167.

Rader, R., Reilly, J., Bartomeus, I., Winfree, R. (2013). Native bees buffer the negative impact of climate warming on honey bee pollination of watermelon crops. Glob. Change Biol. 19, 3103-3110.

Riegelhaupt, E.M., Pareyn, F.G.C.E. (2010). A questão energética, in: Gariglio, M.A., Sampaio, E.V.S.B., Cestaro, L.A., Kageyama, P.Y. Uso sustentável e conservação dos recursos florestais da caatinga. Serviço Florestal Brasileiro, Brasília, p. 65-77.

Santana, M.O. (2007). Atlas das áreas susceptíveis à desertificação do Brasil. MMA, Brasília.

Silva, E.M.S., Freitas, B.M., Silva, L.A., Cruz, D.O., Bomfim, I.G.A. (2005). Biologia floral do pimentão (Capsicum annuum) e a utilização da abelha jandaíra (Melipona subnitida Ducke) como polinizador em cultivo protegido. Rev. Ciênc. Agron. 36, 386-390.

Sparovek, G., Berndes, G., Klug, I.L.F., Barretto, A.G.O.P. (2010). Brazilian agriculture and environmental legislation: status and future challenges. Environ. Sci. Technol. 44, 6046-6053.

Stevenson, T.J., Visser, M.E., Arnold, W., Barrett, P., Biello, S., et al. (2015). Disrupted seasonal biology impacts health, food security and ecosystems. Proc. R. Soc. B 282: 20151453.

Wisz, M.S., Hijmans, R.J., Li, J., Peterson, A.T., Graham, G.H., Guisan, A. (2008). Effects of sample size on the performance of species distribution models. Divers. Distrib. 14, 763-773.

Zanella, F.C.V. (2000). The bees of the Caatinga (Hymenoptera, Apoidea, Apiformes): a species list and comparative notes regarding their distribution. Apidologie 31, 579-592. 